\title{
Physiological characteristics of grapevine under irrigation and fertilization management ${ }^{1}$
}

\author{
Victor Pimenta Martins de Andrade 2 , José Aliçandro Bezerra da Silva ${ }^{3}$, \\ José Sebastião Costa de Sousa ${ }^{2}$, Fábio Freire Oliveira ${ }^{2}$, Welson Lima Simões ${ }^{4}$
}

\section{ABSTRACT}

The viticulture in the semiarid region of Brazil stands out in the country due to the expansion of its cultivated area and increased production, especially in the sub-mid São Francisco Valley. However, the supplying of water and an efficient replacement of nutrients to the soil are essential for these crops, due to the intrinsic climatic conditions of this region, such as low rainfall and high evapotranspiration. This study aimed at evaluating the physiological characteristics of 'Itália' grapevine (Vitis vinifera L.) under irrigation and fertilization management. The experiment was conducted in a randomized block design, with four replications, in a split-plot arrangement, with four irrigation water depths $(0.75,1.00,1.25$ and 1.5 times the crop coefficient) in the plots and four fertilizer rates $(100 \%, 75 \%$, $50 \%$ and $25 \%$, based on the recommended fertilizer rates for this crop) in the subplots, with addition of organic compounds. The leaf water potential, leaf chlorophyll content, relative water content, photosynthesis, stomatal conductance, internal $\mathrm{CO}_{2}$ partial pressure, leaf temperature and biomass accumulation in the berries were evaluated. The highest leaf chlorophyll contents were found in treatments with fertilizer rates of $70-85 \%$. Stomatal conductance decreased with the increasing irrigation water depths, thus reducing the internal $\mathrm{CO}_{2}$ partial pressure and increasing the leaf temperature and air vapor pressure deficit. The reduction of $25 \%$ in the conventional fertilization and irrigation of $135 \%$ of the recommended coefficient resulted in the highest average weight of berries. The highest yields were obtained with the lowest irrigation water depths and fertilizer rates of 50-65\%.

KEYWORDS: Vitis vinifera L.; gas exchange; humic substances.

\section{INTRODUCTION}

The grape production in the São Francisco Valley, in Brazil, has increased mainly due to its regional characteristics of luminosity, temperature and water availability, which enable this crop to

\section{RESUMO}

Aspectos fisiológicos de videira submetida a manejos de irrigação e fertilização

A viticultura na região semiárida, em particular no submédio São Francisco, destaca-se no cenário nacional pela expansão da área cultivada e volume de produção. No entanto, devido às condições climáticas intrínsecas da região, como baixas precipitações pluviométricas e elevada demanda evapotranspirativa, o fornecimento de água é indispensável aos cultivos, assim como uma eficiente reposição de nutrientes ao solo. Objetivou-se analisar variáveis fisiológicas de videira 'Itália' (Vitis vinifera L.) submetida a irrigação e adubação. Utilizou-se delineamento experimental em blocos casualizados, em esquema de parcelas subdivididas, sendo as parcelas quatro fatores de multiplicação do coeficiente de cultura $(0,75 ; 1,00 ; 1,25 ;$ e 1,5$)$ e as subparcelas quatro doses de adubação ( $100 \%, 75 \%$, $50 \%$ e $25 \%$ da adubação recomendada), acrescidas de um produto orgânico, com quatro repetições. Foram avaliadas as variáveis potencial hídrico foliar, índice de clorofila foliar, conteúdo relativo de água, fotossíntese, condutância estomática, pressão parcial de $\mathrm{CO}_{2}$ interno, temperatura foliar e acúmulo de biomassa nas bagas. Os maiores índices de clorofila foliar foram obtidos com adubações de $70-85 \%$. Houve redução da condutância estomática com o aumento da lâmina de irrigação, reduzindo-se, assim, a pressão parcial de $\mathrm{CO}_{2}$ interno e aumentando-se a temperatura foliar e o déficit de pressão de vapor. Com a redução da adubação convencional em $25 \%$ e irrigação de $135 \%$ do coeficiente recomendado, obteve-se o maior peso médio de bagas. As maiores produtividades foram obtidas com as menores lâminas de irrigação e níveis de adubação de 50-65 \%.

PALAVRAS-CHAVE: Vitis vinifera L.; trocas gasosas; substâncias húmicas.

complete two production cycles per year (Pommer 2006, Albuquerque et al. 2013). According to Mascarenhas et al. (2013), the 'Itália' cultivar stands out among most the grapevines grown in the region.

Water availability to crops is restricted in arid and semiarid climate regions, due to their short rainy

1. Manuscript received in Aug./2017 and accepted for publication in Dec./2017 (http://dx.doi.org/10.1590/1983-40632017v4748640).

2. Instituto Federal de Educação, Ciência e Tecnologia do Sertão Pernambucano, Petrolina, PE, Brasil.

E-mails: victorp_hp@hotmail.com, sebastiao.costa@ifsertao-pe.edu.br, fabio.freire@ifsertao-pe.edu.br.

3. Universidade Federal do Vale do São Francisco, Juazeiro, BA, Brasil. E-mail: alissandrojbs@gmail.com.

4. Empresa Brasileira de Pesquisa Agropecuária (Embrapa Semiárido), Petrolina, PE, Brasil.E-mail: welson.simoes@embrapa.br. 
season, requiring the use of irrigation. Under low water availability, plants tend to decrease the water loss by partially closing the stomata, thus avoiding the reduction of water potential. However, this response negatively affects several physiological processes that are important to the plant growth and development, such as transpiration, stomatal conductance, photosynthesis and sugar synthesis, being the main cause of yield reduction (Flexas et al. 2006).

According to Santos \& Kaye (2009), the vegetative growth increases in grapevines grown under high water availability in the soil and competes with the berries for photoassimilates. However, a severe water deficit may negatively affect the grapevine yield and quality (Busato et al. 2011).

Regarding soil management, the organic matter of soils consists mainly of humic substances, which are composed of humins and fulvic and humic acids (Guerra et al. 2008). These humic substances may be used as soil biostimulants and conditioners, improving the soil chemical, physical and microbiological characteristics, such as water and nutrient retention capacity, particle aggregation and porosity (Baldotto et al. 2007).

The interest in using organic acids, mainly humic acids, has increased among fruit farmers in the São Francisco Valley (Cunha et al. 2009). Organic products based on humic and fulvic acids have been used by several grape producers in this region, but their efficiency, when associated with mineral fertilization, has not been scientifically proved.

Considering the importance of water on the growth and development of grapevines, as well as of organic matter on the physicochemical characteristics of the soil, this study aimed at evaluating the physiological characteristics of the 'Itália' grapevine (Vitis vinifera L.) under irrigation and fertilization management and addition of organic compounds based on humic and fulvic acids.

\section{MATERIAL AND METHODS}

The experiment was conducted with 'Itália' grapevine, in a production area of the Instituto Federal de Educação, Ciência e Tecnologia do Sertão Pernambucano, in Petrolina, Pernambuco state, Brazil (9'20'S, 40 $41^{\prime} \mathrm{W}$ and altitude of $418 \mathrm{~m}$ ), in a Yellow Latosol, from October 2014 to February 2015. The climate of the region is BSwh', according to the Köppen classification (Azevedo et al. 2003).
The vineyard was conducted in a pergola system, with spacing of $3.50 \mathrm{~m}$ between rows and $2.50 \mathrm{~m}$ between plants, using a micro-sprinkler irrigation system (low-pressure conventional spray, with emitters spaced $3.50 \mathrm{~m} \times 5.00 \mathrm{~m}$ apart). The plant rows that surrounded the pergola and two plant rows between the treatments were used as borders to avoid effects on the evaluated plants.

The experiment was conducted in a randomized block design, with four replications, in a split-plot arrangement, with four irrigation water depths in the plots and four fertilizer rates in the subplots. The irrigation water depths used consisted of 0.75 , $1.00,1.25$ and 1.5 times the crop coefficient $(\mathrm{Kc})$ recommended by Soares \& Costa (2000) (Table 1), while the fertilization treatments consisted of four fertilizer rates based on the recommended fertilizer rates for this crop: $100 \%, 75 \%, 50 \%$ and $25 \%$ (IPA 2008 ), with addition of organic compounds based on humic and fulvic acids at the concentration of $20 \%\left(\mathrm{v} \mathrm{w}^{-1}\right)$. The organic product used was composed of $6 \%$ of humic acid and $5 \%$ of fulvic acid $\left(\mathrm{vv}^{-1}\right)$. Each experimental plot consisted of one evaluated plant.

The reference evapotranspiration (ETo) was determined using the Penman-Monteith model (Allen et al. 1998), based on meteorological data from an automatic meteorological station located at $230 \mathrm{~m}$ from the experimental area. The meteorological data collection and irrigations were carried out daily, based on the crop evapotranspiration $\left(\mathrm{ET}_{\mathrm{c}}=\mathrm{ETo} \mathrm{x} \mathrm{Kc}\right)$.

The soil of the experimental area was fertilized according to recommendations of the Instituto Agronômico de Pernambuco (IPA 2008), based on the soil chemical analysis (Table 2). The fertilizers were divided into eight applications, considering the crop requirements in each phenological stage (Andrade

Table 1. Crop coefficient (Kc) for 'Itália' grapevine, according to its phenological stages, given in days after pruning (DAP).

\begin{tabular}{lcc}
\hline \multicolumn{1}{c}{ Phenological stage } & DAP & Kc \\
\hline Sprouting period & $0-8$ & 0.59 \\
Vegetative development & $9-28$ & 0.60 \\
Pre-flowering and full flowering & $29-40$ & 0.69 \\
First fruit growth stage & $41-55$ & 1.11 \\
Fruit growth stop & $56-80$ & 0.90 \\
Second fruit growth stage & $81-110$ & 1.12 \\
Final fruit ripening & $111-130$ & $1.00-0.60$ \\
Phenological resting & $131-160$ & 0.75 \\
\hline
\end{tabular}

Source: Soares \& Costa (2000). 
Table 2. Chemical analysis of soil samples of the experimental area collected in the plant rows.

\begin{tabular}{ccccccccc}
\hline Layer & $\mathrm{pH}$ & $\mathrm{P}\left(\mathrm{Melich}^{-1}\right)$ & $\mathrm{K}$ & $\mathrm{Ca}$ & $\mathrm{Mg}$ & $\mathrm{Na}$ & $\mathrm{Al}$ & $\mathrm{H}+\mathrm{Al}$ \\
\hline $\mathrm{cm}$ & $\mathrm{H}_{2} \mathrm{O}$ & $\mathrm{mg} \mathrm{dm}^{-3}$ & & & & $\mathrm{cmol}_{\mathrm{c}} \mathrm{dm}^{-3}$ & & \\
\hline $0-20$ & 5.76 & 48.34 & 0.56 & 1.60 & 2.00 & 0.07 & - & 2.48 \\
\hline
\end{tabular}

Júnior et al. 2007). The fertilizer rates applied were $150 \mathrm{~kg} \mathrm{ha}^{-1}$ of $\mathrm{N}$ (urea, $45 \%$ of N), $80 \mathrm{~kg} \mathrm{ha}^{-1}$ of $\mathrm{P}_{2} \mathrm{O}_{5}$ (monoammonium phosphate, $52 \%$ of $\mathrm{P}_{2} \mathrm{O}_{5}$ and $12 \%$ of $\mathrm{N}$ ) and $100 \mathrm{~kg} \mathrm{ha}^{-1}$ of $\mathrm{K}_{2} \mathrm{O}$ (potassium chloride, $58 \%$ of $\mathrm{K}_{2} \mathrm{O}$ ).

The plants were pruned on October 24 (2014), and their fruits were harvested on February 21 (2015), at 120 days after pruning (DAP). The plants were in the third production cycle under the same experimental treatments.

The leaf relative water content was analyzed at 33, 88 and 115 DAP. Two discs of leaf blades without the main veins were taken from plants of each plot. The fresh weight of the leaf samples was measured shortly after the sample collection. The turgid weight was measured at $24 \mathrm{~h}$ after the samples were immersed in distilled-deionized water, and the dry weight was measured after the samples were dried in an oven at $50{ }^{\circ} \mathrm{C}$, for $72 \mathrm{~h}$. The relative water content was estimated using the ratio between the fresh weight minus dry weight and turgid weight minus dry weight (Smart \& Bingham 1974).

The leaf water potential was measured in one leaf per replication at $33 \mathrm{DAP}$, using a Scholander pressure pump (PMS Instrument Co, model 1000). The leaf water potential was measured at 04:00 a.m., when the stomata were closed and the leaf water potential was balanced with the soil potential. The collected leaves were placed in the chamber of the pressure pump, and the applied pressure was measured until sap exudation through the cross section of the leaf petiole (Turner 1981).

The leaf chlorophyll $a, b$ and total contents were evaluated in one leaf per replication at 34 , 88 and 115 DAP, using a portable device (Falker, ClorofiLOG CFL 1030).

Photosynthesis, stomatal conductance, internal $\mathrm{CO}_{2}$ partial pressure, leaf transpiration, leaf temperature, air vapor pressure deficit and photosynthetically active radiation were measured at 38 and 115 DAP, using a portable infra-red photosynthesis analyzer (Licor, Infra-Red Gas Analyzer Li 6400). The measurements were performed at 09:00 a.m., with one measurement per replication. The last replication of each treatment was discarded to reduce the time between the first and the last reading, thus reducing the detection of changes from environmental factors.

The average berry weight was estimated by weighing 25 berries of each plant in an analytical scale. The berries were sampled in different bunches from the lower, middle and upper positions. Grape yield was estimated after harvest, considering the production of each plant and the spacing used.

The data were subjected to analysis of variance, and means with significant differences were subjected to regression analysis.

\section{RESULTS AND DISCUSSION}

The interaction between the irrigation and fertilization treatments had no significant effect at $5 \%$ on the evaluated variables. The curves of the leaf water potential and relative water content had similar variations, denoting the correlation between these variables (Figure 1). However, the fertilizer rates had no effects on these variables.

The irrigation and fertilization treatments had no significant effect on the relative water content of the plants in the first and third evaluations at 33 and 115 DAP, respectively. However, the relative water content showed a linear increase with increasing water depths, in the second evaluation (88 DAP) (Figure 1A). This difference was probably due to the time of evaluation, which coincided with the highest Kc (1.12). Schultz (1997) and Souza et al. (2001) also found a correlation between relative water content and water depths in grapevine leaves.

The estimated maximum leaf water potential was $-0.27 \mathrm{MPa}$ at $33 \mathrm{DAP}$, with water depth of 1.42 times the Kc (Figure 1B). Therefore, irrigations with water depths with more than 1.42 times the Kc did not increase the leaf water potential of the plant. According to Hsiao (1973), a leaf water potential below $-0.5 \mathrm{MPa}$ at dawn is considered harmful to grapevines. This result was not found with the water 

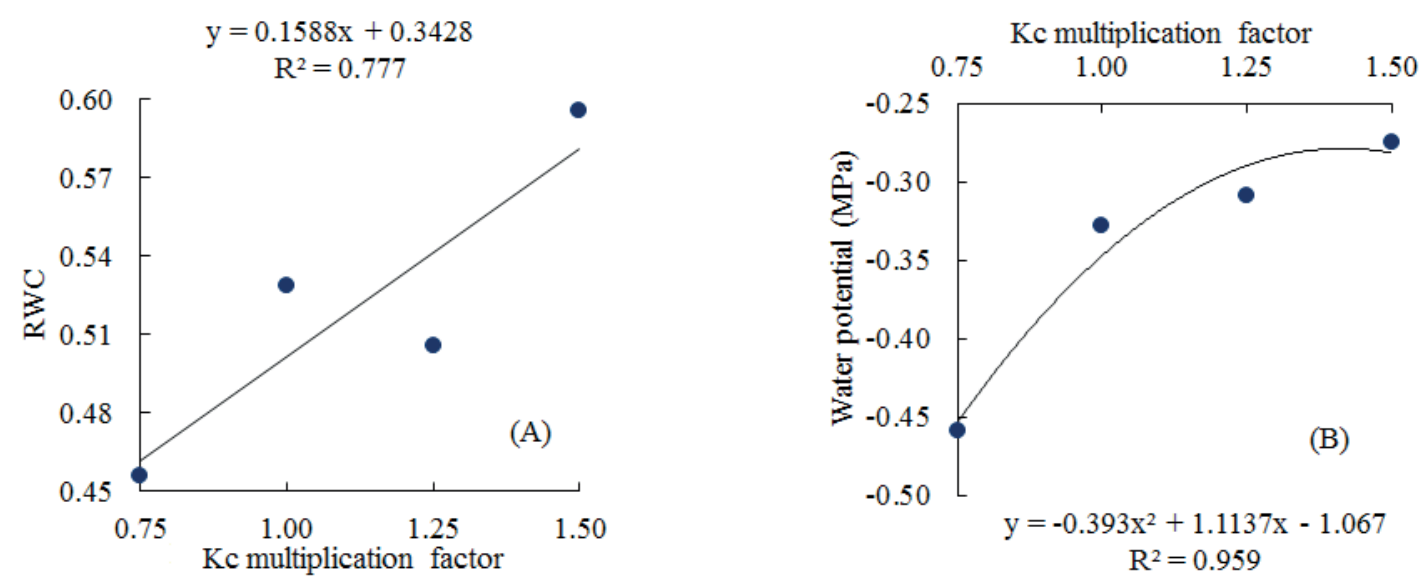

Figure 1. Relative water content (RWC) measured at 88 days after pruning (DAP) (A) and leaf water potential (MPa) (LWP) at 33 DAP (B) of 'Itália' grapevine, as a function of irrigation water depths.

depths used, and the lowest leaf water potential observed was -0.45 Mpa.

The irrigation treatments had no effects on the chlorophyll $a$ and $b$ and total chlorophyll contents. Similar results were found by Taiz \& Zeiger (2013), when evaluating chlorophyll contents under water stress conditions.

The chlorophyll $a, b$ and total chlorophyll contents of plants, as a function of fertilization treatments, were different at 34 and 88 DAP (Figure 2). However, they showed no differences at the third evaluation (115 DAP). The chlorophyll content increased with increasing fertilizer rates, probably due to the amount of nitrogen applied to the soil. Tecchio et al. (2011) found similar results in the 'Niágara Rosada' cultivar, with significant positive correlations between leaf nitrogen content and chlorophyll content in the leaf blades. Costa et al. (2012) also observed similar results, when evaluating maize leaves, with a linear increase in the chlorophyll content with increasing nitrogen fertilizer rates up to $200 \mathrm{~kg} \mathrm{ha}^{-1}$.

The maximum chlorophyll $a$ and total chlorophyll contents at 34 DAP were 44.22 and 57.56 , with fertilizer rates of $72.08 \%$ and $80.25 \%$, respectively (Figure 2). The maximum chlorophyll $a, b$ and total chlorophyll contents at 88 DAP were $43.55,13.18$ and 56.72 , with fertilizer rates of $69.25 \%, 72.33 \%$ and $70.27 \%$, respectively.

According to these results, fertilizer rates of $70.27-80.25 \%$ would result in higher total chlorophyll contents in grapevine leaves. The chlorophyll content is linearly correlated with the $\mathrm{N}$ content in the plant (Fontes \& Araújo 2007). Thus, these fertilizer rates may result in grapevines with higher $\mathrm{N}$ uptake. According to Silveira et al. (2003), a low N rate hinders plant growth and yield, while a high $\mathrm{N}$ rate increases production costs and causes environmental damage, due to nitrate leaching. Therefore, an adequate use of nitrogen improves the plant nutritional status and dry matter production.

The stomatal conductance and the internal $\mathrm{CO}_{2}$ partial pressure decreased linearly, while the leaf temperature and air vapor pressure deficit increased, with increasing water depths (Figure 3).

The excess or scarcity of water induce stomatal closure. Martinazzo et al. (2013) evaluated plum trees subjected to both conditions and found a reduced $\mathrm{CO}_{2}$ diffusion to the leaf mesophyll, and reduced internal $\mathrm{CO}_{2}$ partial pressure. These results are in accordance with the ones observed in the present study.

According to Ávila Netto et al. (2000), the Kc for 'Itália' grapevine crops in the sub-mid São Francisco Valley ranges from 0.50 (maturation) to 0.74 (berry filling). These values are lower than the ones observed by Soares \& Costa (2000) (0.59-1.12). According to the results found in the present study, the Kc recommended by Soares \& Costa (2000) were probably excessive for this production cycle, in which the increase in water depths induced the stomatal closure. This stomatal closure may have caused the increased leaf temperature and air vapor pressure deficit, with increasing water depths (Figure 3).

Regarding the gas exchange variables, the photosynthesis and leaf transpiration were similar in all treatments, and none of the gas exchange variables presented a significant difference, as a 
function of fertilizer rates. Contrastingly, Nascimento et al. (2016) found a decreased photosynthetic rate in 'Syrah' grapevine subjected to irrigation deficit. However, Costa \& Marenco (2007) observed a low correlation between stomatal conductance and photosynthesis in andiroba (Carapa guianensis) trees. Thus, both photosynthesis and stomatal conductance are plant parameters that respond simultaneously to a set of complex factors that interact coordinately.

The average berry weight presented a quadratic response to water depths when subjected to the fertilizer rate of $75 \%$, and a negative linear response to the fertilizer rates when subjected to the water depth of 1.25 times the Kc (Figures 4A and 4B). The fertilizer rate of $75 \%$ with water depth of 1.35 times the Kc resulted in the highest average berry weight $(7.29 \mathrm{~g})$. The berry weight increased with increasing water depths, probably due to the amount of water $(81 \%)$ in the grape composition (Vicentino et al. 2011). However, irrigation requires an adequate management, since an excess of water may cause excessive vegetative growth and dilution of soluble solids, thus breaking the berries (Keller et al. 2006).

The berry weight decreased with increasing fertilizer rates, when using the water depth of 1.25 times the Kc (Figure 4B). The application of high
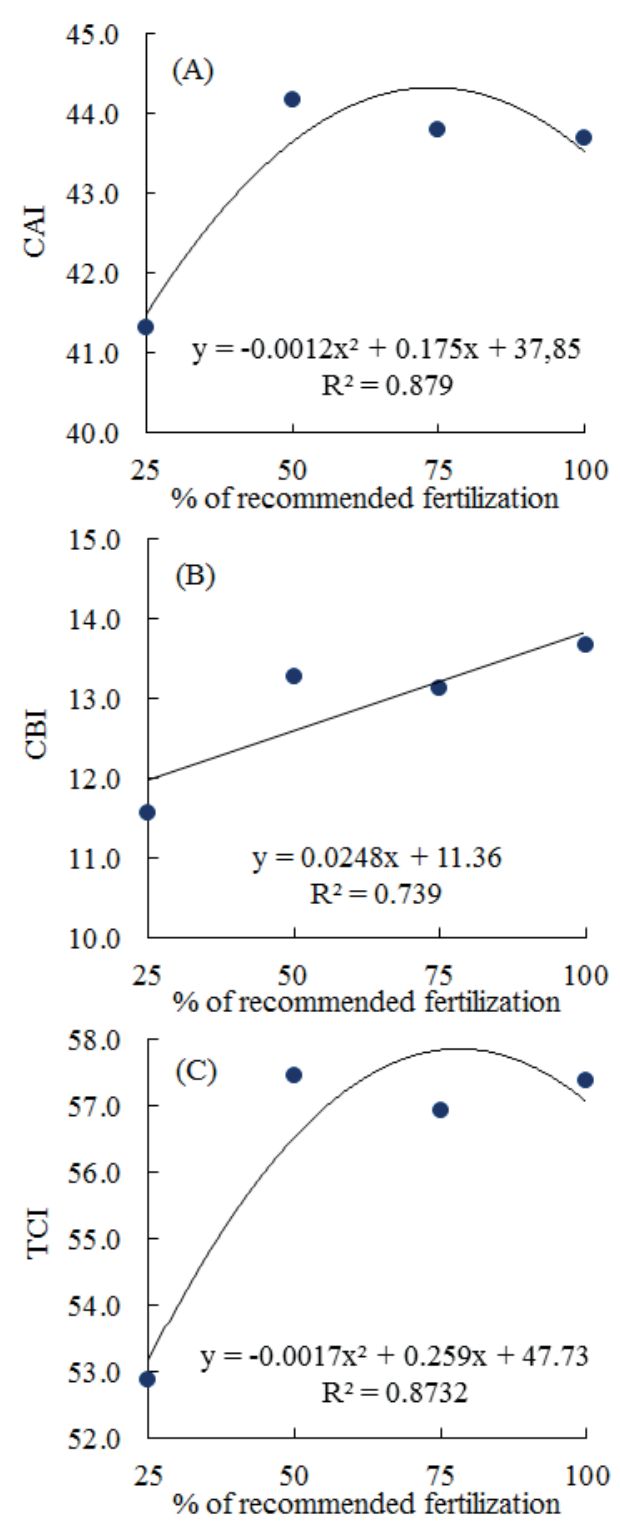
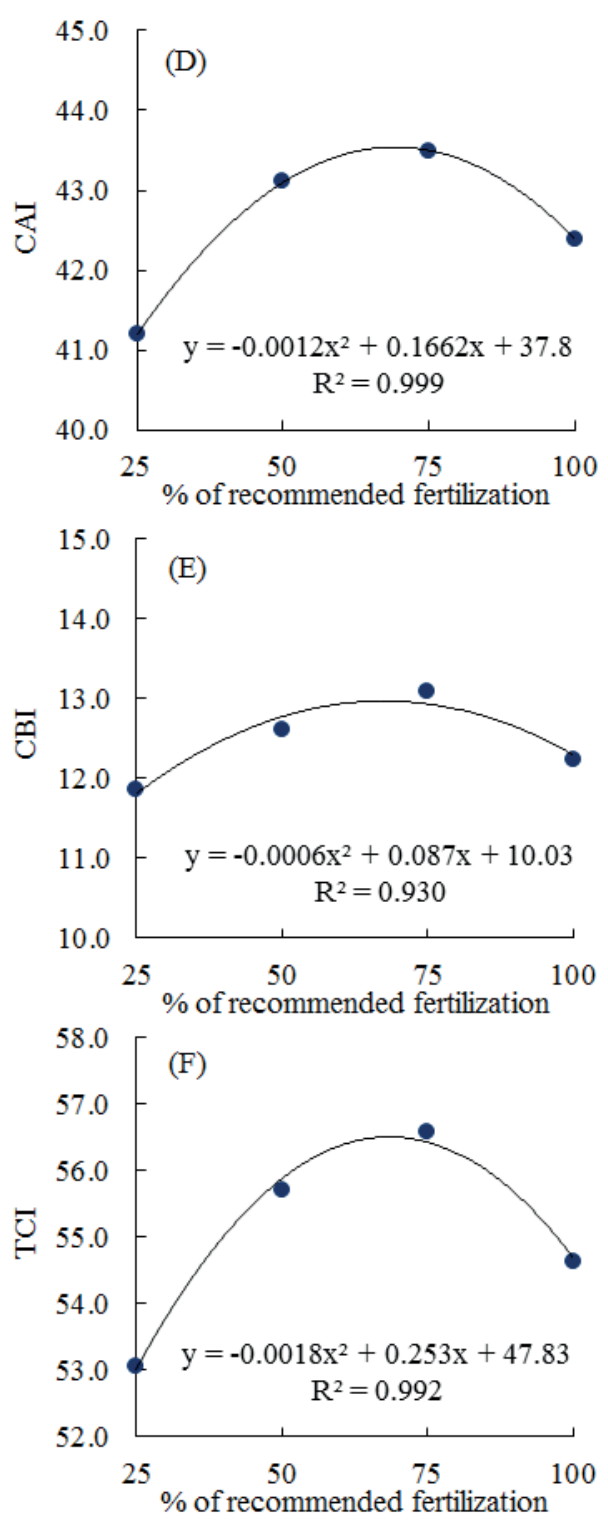

Figure 2. Relative index of leaf chlorophyll $a(\mathrm{CAI}), b(\mathrm{CBI})$ and total chlorophyll (TCI) contents in Itália' grapevine, at 34 days after production pruning (DAPP) (A, B and C) and at 88 DAPP (D, E, and F), as a function of fertilization treatments. 
fertilizer rates may reduce the soil osmotic potential, as well as water availability to plants, thus reducing the berry growth (Andrade Júnior et al. 2007).

According to the regression analysis, the grape yield varied significantly with increasing fertilizer rates when using water depths of 1.00 and 0.75 times the Kc (Figures 5A and 5B, respectively), and with increasing water depths when using fertilizer rates of $100 \%, 75 \%$ and $50 \%$ (Figures $5 \mathrm{C}, 5 \mathrm{D}$ and $5 \mathrm{E}$, respectively).
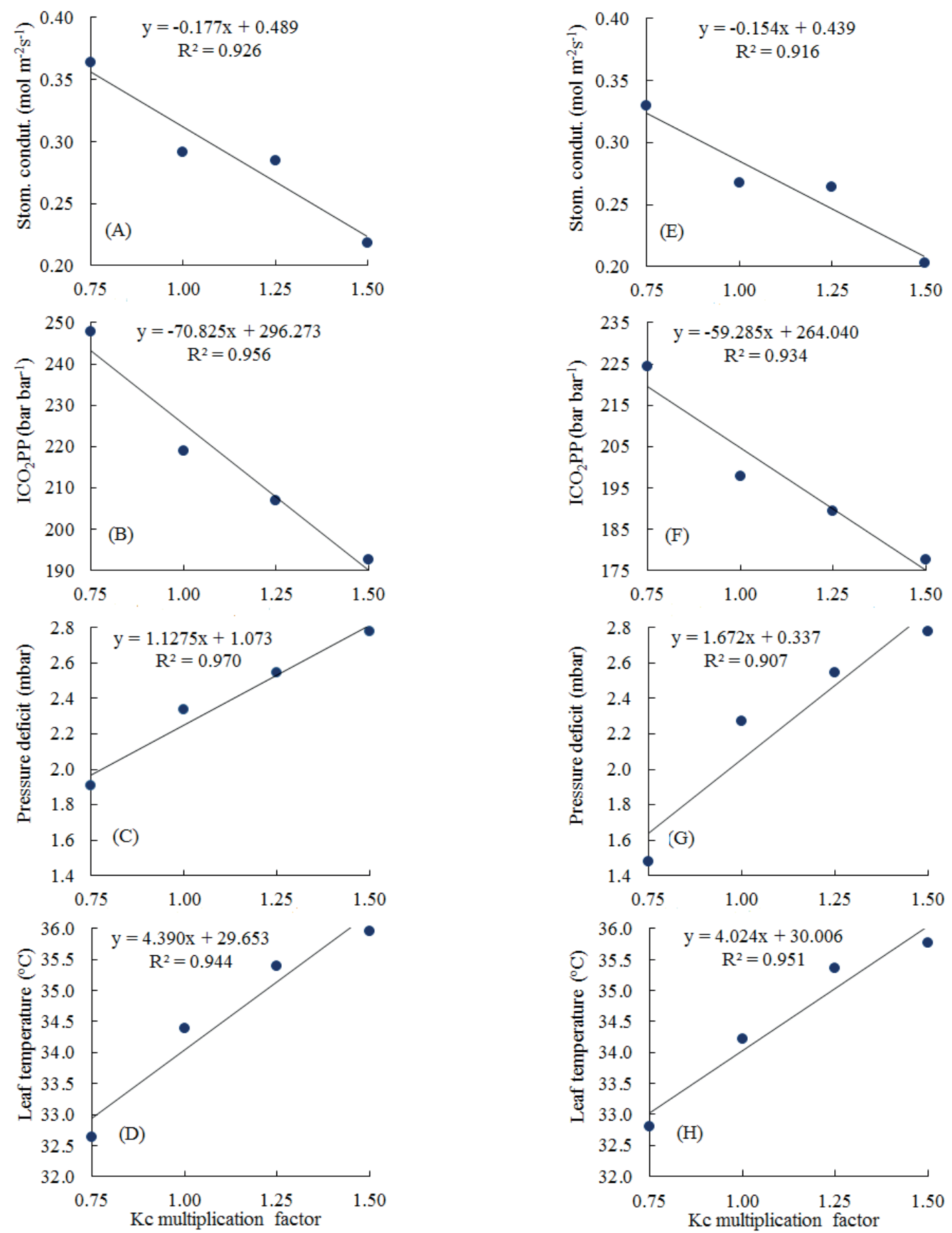

Figure 3. Stomatal conductance, internal $\mathrm{CO}_{2}$ partial pressure ( $\left.\mathrm{ICO}_{2} \mathrm{PP}\right)$, air vapor pressure deficit and leaf temperature of 'Itália' grapevine, at 39 days after pruning $\operatorname{DAP}(\mathrm{A}, \mathrm{B}, \mathrm{C}$ and D) and $115 \mathrm{DAP}(\mathrm{E}, \mathrm{F}, \mathrm{G}$ and $\mathrm{H})$, as a function of irrigation water depths. 
A grape yield of $13.81 \mathrm{~kg}$ plant $^{-1}$ was found in plants subjected to the water depth of 0.75 times the $\mathrm{Kc}$ and fertilizer rate of $65 \%$ (Figure 5B). Contrastingly, the maximum grape yield was $8.55 \mathrm{~kg}$ plant $^{-1}$ with a water depth of 1.00 times the $\mathrm{Kc}$, when using a fertilizer rate of $71 \%$ (Figure $5 \mathrm{~A}$ ). These results are similar to the ones indicated by Ávila Netto et al. (2000) - Kc of 0.50 (maturation) to 0.74 (berry filling) - for 'Itália' grapevine grown in the sub-mid São Francisco Valley. In an experiment carried out in Chile, Ferreyra et al. (2006) found no differences for yield in 'Crimson Seedless' grapevine, when using water depths of 0.50 and 1.00 times the ETc.

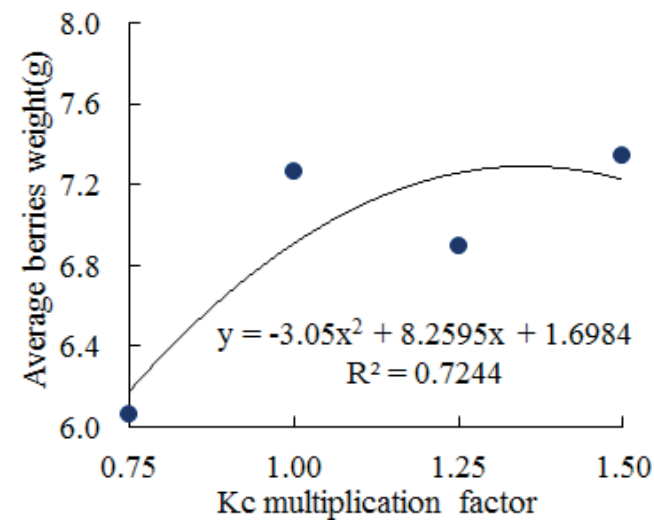

A grape yield of $13.75 \mathrm{~kg}$ plant $^{-1}$ was found with the fertilizer rate of $50 \%$ and water depth of 0.75 times the Kc (Figure 5E). The lowest yield in this treatment was $3.40 \mathrm{~kg}$ plant ${ }^{-1}$, when using the water depth of 1.42 times the Kc. This minimum yield resulted from fertilizer rates of $100 \%$ and $75 \%$, using water depths of 1.39 and 1.65 times the Kc, respectively (Figures 5C and 5D). These results denote the increasing efficiency of the mineral fertilization with the organic product used, which reduced the amount of fertilizer applied, since the optimal fertilizer rate was between $50 \%$ and $65 \%$, based on the recommended mineral fertilizer rates for 'Itália' grapevine.

Figure 4. Average berries weight of 'Itália' grapevine, as a function of irrigation water depths (A) and fertilizer rates (B).
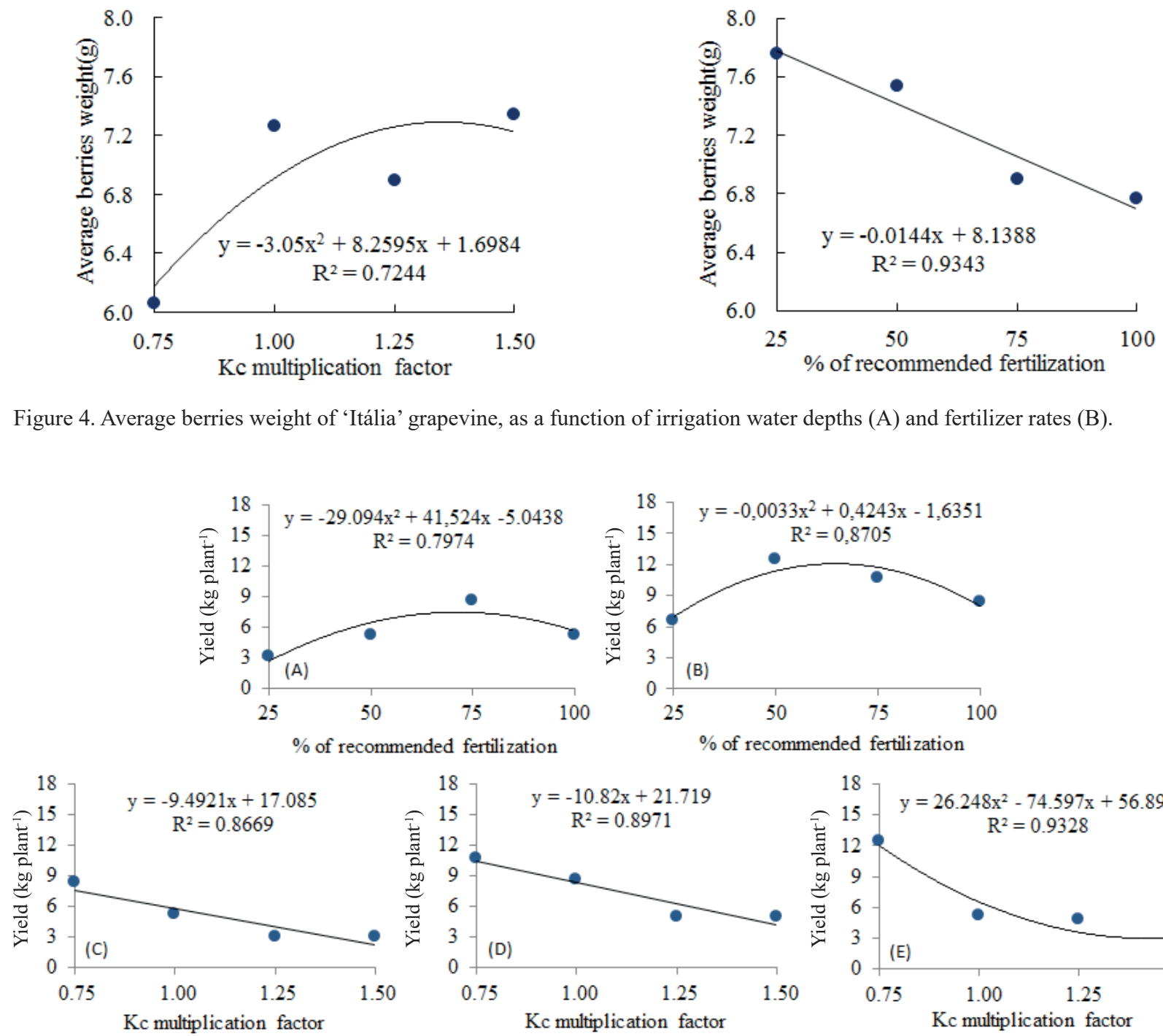

Figure 5. 'Itália' grapevine yield, as a function of fertilizer rates with irrigation water depths of 1.00 (A) and 0.75 (B) times the Kc recommended by Soares and Costa (2000), and as a function of irrigation water depths with fertilizer rates of $100 \%(\mathrm{C})$, $75 \%(\mathrm{D})$ and $50 \%(\mathrm{E})$, based on the recommended mineral fertilizer rates for this crop. 


\section{CONCLUSIONS}

1. The increasing irrigation water depths up to 1.35 times the recommended Kc increases the cell water content in 'Itália' grapevine and, consequently, increases the average berry weight;

2. Soil fertilization with humic and fulvic acids, together with mineral fertilizers rates of up to $80.25 \%$, based on the recommended mineral fertilizer rates for 'Itália' grapevine, increases the chlorophyll synthesis, but does not affect the $\mathrm{CO}_{2}$ assimilation rate;

3. The reduction of the irrigation water depth increases linearly the stomatal conductance;

4. The highest yields of 'Itália' grapevine are obtained with the lowest irrigation water depths and fertilizer rates of 50-65\%.

\section{REFERENCES}

ALBUQUERQUE, A. H. P. et al. Irrigação e fertirrigação potássica na cultura da videira em condições semiáridas. Pesquisa Agropecuária Tropical, v. 43, n. 3, p. 315-321, 2013.

ALLEN, R. G. et al. Crop evapotranspiration: guidelines for computing crop water requirements. Rome: FAO, 1998.

ANDRADE JÚNIOR, A. S. et al. Frequência de aplicação de nitrogênio e de potássio via água de irrigação por gotejamento na cultura da melancia em Parnaíba, PI. Agropecuária Científica no Semiárido, v. 3, n. 1, p. 1-7, 2007.

ÁVILA NETTO, J. et al. Exigências hídricas da videira na região do submédio São Francisco. Pesquisa Agropecuária Brasileira, v. 35, n. 8, p. 1559-1566, 2000.

AZEVEDO, P. V.; SILVA, B. B.; SILVA, V. P. R. Water requirements of irrigated mango orchards in Northeast Brazil. Agricultural Water Management, v. 58, n. 3, p. 241-245, 2003.

BALDOTTO, M. A. et al. Propriedades redox e grupos funcionais de ácidos húmicos isolados de adubos orgânicos. Revista Brasileira de Ciência do Solo, v. 31, n. 3, p. 465-475, 2007.

BUSATO, C. C. M. et al. Manejo da irrigação e fertirrigação com nitrogênio sobre as características químicas da videira 'Niágara Rosada'. Ciência Rural, v. 41, n. 7, p. 1183-1188, 2011.

COSTA, G. F.; MARENCO, R. A. Fotossíntese, condutância estomática e potencial hídrico foliar em árvores jovens de andiroba (Carapa guianensis). Acta Amazonica, v. 37, n. 2, p. 229-234, 2007.
COSTA, R. N. et al. Adubação nitrogenada no consórcio de milho com duas espécies de braquiária em sistema plantio direto. Pesquisa Agropecuária Brasileira, v. 47, n. 8, p. 1038-1047, 2012.

CUNHA, T. J. F. et al. Ácidos húmicos em solo fertirrigado no Vale do São Francisco. Revista Brasileira de Ciência do Solo, v. 33, n. 6, p. 1583-1592, 2009.

FERREYRA, R. et al. Efecto del agua aplicada en las relaciones hídricas y productividad de la vid 'Crimson Seedless'. Pesquisa Agropecuária Brasileira, v. 41, n. 7, p. 1109-1118, 2006.

FLEXAS, J. et al. Keeping a positive carbon balance under adverse conditions: responses of photosynthesis and respiration to water stress. Physiologia Plantarum, v. 127, n. 3, p. 343-352, 2006.

FONTES, P. C. R.; ARAÚJO, C. Adubação nitrogenada de hortaliças: princípios e práticas com o tomateiro. Viçosa: UFV, 2007.

GUERRA, J. C. M. et al. Macromoléculas e substâncias húmicas. In: SANTOS, G. A. Fundamentos da matéria orgânica do solo: ecossistemas tropicais \& subtropicais. 2. ed. Porto Alegre: Metrópole, 2008. p. 19-26.

HSIAO, T. C. Plant response to water stress. Annual Review of Plant Physiology, v. 4, n. 1, p. 519-570, 1973.

INSTITUTO AGRONÔMICO DE PERNAMBUCO (IPA). Recomendação de adubação para o estado de Pernambuco. Recife: IPA, 2008.

KELLER, M. et al. Ripening grape berries remain hydraulically connected to the shoot. Journal of Experimental Botany, v. 57, n. 11, p. 2577-2587, 2006.

MARTINAZZO, E. G. et al. Atividade fotossintética em plantas de ameixeira submetidas ao déficit hídrico e ao alagamento. Ciência Rural, v. 43, n. 1, p. 35-41, 2013.

MASCARENHAS, R. de J. et al. Qualidade sensorial e físico-químico de uvas finas de mesa cultivadas no submédio São Francisco. Revista Brasileira de Fruticultura, v. 35, n. 2, p. 546-554, 2013.

NASCIMENTO, R. L. et al. Trocas gasosas e composição físico-química de vinhos em função de estratégias de irrigação. Irriga, special ed., p. 205-217, 2016.

POMMER, C. V. Double cropping of table grapes in Brazil. Chronica Horticulturae, v. 6, n. 2, p. 22-25, 2006.

SANTOS, A. O.; KAYE, O. Composição quali-quantitativa da produção de 'Syrah' cultivada sob estresse hídrico transiente. Revista Brasileira de Engenharia Agrícola e Ambiental, v. 13, n. 3, p. 272-281, 2009.

SCHULTZ, H. R. Water relations and photosynthetic response of two grapevine cultivars of different geographical 
origin during water stress. Acta Horticulturae, v. 427, n. 1, p. 251-265, 1997.

SILVEIRA, P. M.; BRAZ, A. J. B. P.; DIDONET, A. D. Uso de clorofilômetro como indicador da necessidade de adubação nitrogenada em cobertura no feijoeiro. Pesquisa Agropecuária Brasileira, v. 38, n. 9, p. 1083-1087, 2003.

SMART, R. E.; BINGHAM, G. E. Rapid estimates of relative water content. Plant Physiology, v. 53, n. 2, p. 258-260, 1974.

SOARES, J. M.; COSTA, F. F. Irrigação na cultura da videira. Informe Agropecuário, v. 19, n. 194, p. 58-69, 2000.

SOUZA, C. R.; SOARES, A. M.; REGINA, M. A. Trocas gasosas de mudas de videira, obtidas por dois porta- enxertos, submetidas à deficiência hídrica. Pesquisa Agropecuária Brasileira, v. 36, n. 10, p. 1221-1230, 2001.

TAIZ, L.; ZEIGER, E. Fisiologia vegetal. 5. ed. Porto Alegre: Artmed, 2013.

TECCHIO, M. A. et al. Teores foliares de nutrientes, índice relativo de clorofila e teores de nitrato e de potássio na seiva do pecíolo na videira 'Niagara Rosada'. Revista Brasileira de Fruticultura, v. 33, n. 2, p. 649-659, 2011.

TURNER, N. C. Techniques and experimental approaches for the measurement of plant water status. Plant and Soil, v. 58, n. 1, p. 339-366, 1981.

VICENTINO, S. L. et al. Filmes de amidos de mandioca modificados para recobrimento e conservação de uvas. Química Nova, v. 34, n. 8, p. 1309-1314, 2011. 